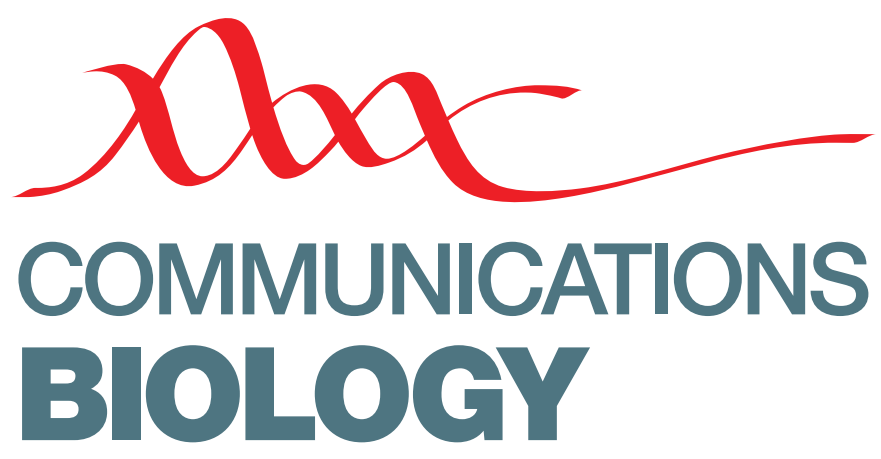

\title{
Author Correction: Detecting protein and post-translational modifications in single cells with iDentification and qUantification sEparaTion (DUET)
}

Yandong Zhang, Changho Sohn (1D, Seoyeon Lee, Heejeong Ahn, Jinyoung Seo (D), Junyue Cao \& Long Cai (D)

Correction to: Communications Biology https://doi.org/10.1038/s42003-020-01132-8, published online 3 August 2020.

In the original published version of the article, co-author Seoyeon Lee's name was incorrectly spelled as Seoyoen Lee. The error has been corrected in the HTML and PDF versions of the article.

Published online: 18 August 2020

\footnotetext{
(c) (1) Open Access This article is licensed under a Creative Commons Attribution 4.0 International License, which permits use, sharing, adaptation, distribution and reproduction in any medium or format, as long as you give appropriate credit to the original author(s) and the source, provide a link to the Creative Commons license, and indicate if changes were made. The images or other third party material in this article are included in the article's Creative Commons license, unless indicated otherwise in a credit line to the material. If material is not included in the article's Creative Commons license and your intended use is not permitted by statutory regulation or exceeds the permitted use, you will need to obtain permission directly from the copyright holder. To view a copy of this license, visit http://creativecommons.org/licenses/by/4.0/.
}

() The Author(s) 2020 